\title{
IN SEARCH OF THE TRADITIONAL ARCHITECTURAL IDENTITY: THE CASE OF MADINAH, SAUDI ARABIA
}

Randah Ashour

Faculty of Art, Design, and Humanities, De Montfort University, Leicester, UK

abdbasri@hotmail.com

\begin{abstract}
Rowshan is the projected latticework window, commonly found in façades of traditional dwellings in Madinah. Due to climatic and social functions that Rowshan provides, it achieved widespread popularity in the traditional architecture of Madinah, which gave the city its unique architectural identity. The objective of this research is to explore the professionals' opinions toward the erosion of the traditional architectural identity within contemporary architecture in Madinah, as well as the ensuing decline in the use of Rowshan element that defines this particular style of architecture and ascertaining whether they are interested in reviving Rowshan element in their architectural projects. The method of this research is interviews with 15 professionals who were carried out in Madinah between 1/10/2016 - 1/12/2016. The interview questions were semi-structured, and the data were analyzed using thematic analysis. Overriding opinions concluded that Rowshan's legacy is of great value in Madinah society, and the need to preserve it within contemporary architecture is essential. The respondents' opinions also agreed that ways should be found to develop Rowshan's designs, which would ensure that the form of Rowshan is integrated with its function.
\end{abstract}

KEYWORDS:

Rowshan; identity; Madinah; Saudi Arabia

\section{INTRODUCTION}

The religious tourism in Saudi Arabia is part of the government's 2020 National Transformation Programme and Vision 2030, which depend on non-oil sources of income, with religious tourism being considered the most important of these sources of income. The Vision 2030 plan aims to draw 6 million pilgrims to Hajj and 30 million pilgrims to Umrah annually [1]. Although visiting Madinah is not a rite of the Hajj or Umrah journey, the unique merits of Madinah attract the hearts of millions of Muslims each year, to visit the Prophet's city, his Mosque and his sacred tomb. According to Madinah Development Authority, the total number of religious visits (including Hajj and Umrah) to Madinah is expected to increase from 7 million in 2014 to 10 million by 2025 [2]. This massive yearly influx of visitors from all over the world has dramatically changed the traditional architectural fabric of Madinah; especially the central historical area (the Central District) around the Prophet's Mosque as most of the traditional buildings in the Central District have been destroyed to make room for expansion of the Prophet's Mosque and provision of accommodation and facilities to the visitors around the year (Figure 1). According to an estimate by the Washington-based Gulf Institute, more than $95 \%$ of the traditional buildings in the two Holy Cities of Makkah and Madinah, which have existed since the seventh century, have been demolished in the last 20 years [3].

Traditional buildings, including residential properties, mosques, libraries, wells, and public paths, in the Central District, which have existed since the seventh century, have been destroyed and replaced by luxury five-stars hotels and spas, restaurants, coffee shops, car parks and shopping malls for global brands. The real controversy arises from the nature of the expansion. The main challenge for the local authorities was developing an area that has a great traditional heritage and a long history. Unfortunately, it was clear that developers and planners had chosen to undertake a mass development project for the area rather than undertaking a rehabilitation project and finding a contemporary architectural language that preserves the traditional and historical values of the place. As a result, traditional buildings in the Central District, which have existed since the seventh century, have been destroyed and replaced by luxury five-stars hotels and spas, restaurants, coffee shops, car parks, and shopping malls for global brands [4][5][6]. Although the development project had offered a luxurious experience and first-class services to millions of visitors each year, it failed to deliver the authentic experience of the place. It turned the central historical area into a strange spatial scope, which caused a state of visual, intellectual, and even spiritual confusion for the local people as well as for the visitors. This new, modern 
architecture does not reflect. It is inconsistent with the local realities and elements of Madinah's traditional architecture, which has created a negative image of architecture and design in the region (Figure 2).

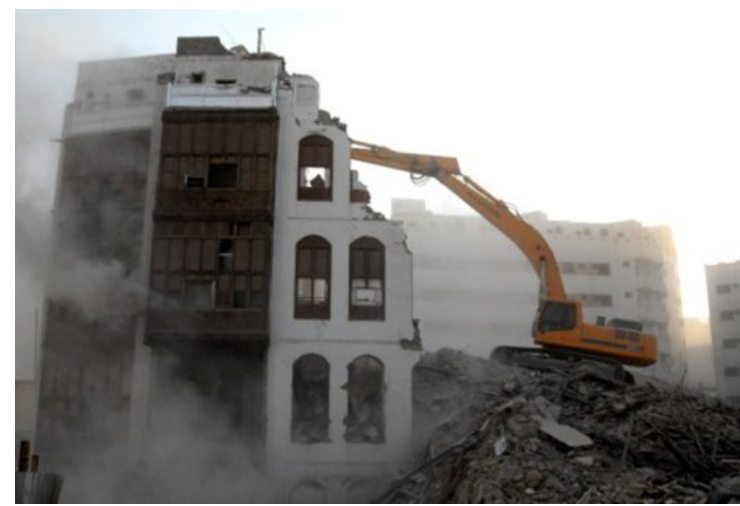

Figure 1. The massive demolishing processes of traditional neighborhoods with their traditional landmarks to give room for colossal Holy Mosque development and expansion programs [7]

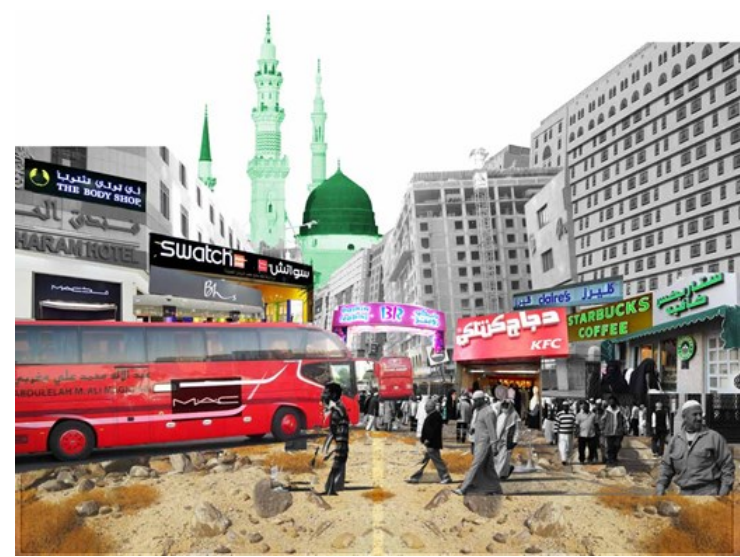

Figure 2. Panoramic image shows the transformation of the Central District of Madinah into a strange spatial scope conflict with the traditional and historical values of the place in the name of urbanization and profitability [4].

On the other hand, there is clear evidence that during recent decades, the Islamic world has been increasingly influenced by Western culture. It can be observed that there is a rapid change taking place in the ideology and nature of the architecture in Saudi Arabia since the onset of the oil economy in 1950-1970, and this has been reinforced by the current process of globalization in the world [8]. The rapid urbanization and technological advances have resulted in additional standardization of built-up environments, thus depriving human habitats of cultural and regional identity [9]. The openness to global markets and gaining access to building materials and new construction techniques from one side, and the recruitment of skilled foreign labor and technical expertise offices which have no idea about the architectural legacy of Madinah from other side have greatly contributed to the gradual erosion of the traditional architectural identity in the building industry in Madinah.

The present study aims to explore the professionals' opinions, through conducting interviews, toward the erosion of the traditional architectural identity within contemporary architecture in Madinah, as well as the ensuing decline in the use of Rowshan element that defines this particular style of architecture and ascertaining whether they are interested in reviving Rowshan element in their architectural projects.

The specific objectives are:

1. To explore the attitudes of the experts and professionals towards the vernacular architecture of Madinah.

2. To explore the attitudes of the experts and professionals towards the contemporary architecture of Madinah.

3. To identify the reasons behind the dwindling traditional architectural identity in contemporary building designs.

4. To evaluate the attempts to revive traditional architectural identity in contemporary architecture.

5. To identify the stakeholders/key players responsible for determining the pattern and style of design in the contemporary building system.

6. To explore the experts' opinions towards the importance of preserving the traditional architectural elements within the contemporary architecture in Madinah.

\section{METHODS}

\section{DESIGNING THE INTERVIEW}

The interview was divided into three sections. The first section used background questions to provide demographic data about the interviewees' names, nationality, educational level, country of qualification, job title, and several years of experience. The second section involved questions designed to explore the interviewees' opinions and attitudes toward: (1) the vernacular architecture of Madinah; (2) the contemporary architecture of Madinah; (3) reasons behind dwindling traditional architectural identity in contemporary building designs; (4) attempts to revive traditional architectural identity in contemporary architecture and (5) the Stakeholders/Key players responsible for determining the pattern and style of design in the contemporary building system. The third section involved questions that reflected the opinions and feelings of the participants toward the culture of Rowshan in Madinah and the importance of preserving it within contemporary architecture in Madinah. The interviews consisted of nine questions, excluding those concerned with demography. Each interview took around one hour. Before interviews, permission was sought, and appointments were made.

The interviews followed a semi-structured format with a series of open questions to allow the interviewees to talk openly about their opinions within a flexible but focused framework. This qualitative method also allows the participants to discuss further and raised issues that the author may not have considered. The indepth interviews involved individual one to one (faceto-face) conversations, during which the author interviewed each interviewee separately. The advantage of this type of interview is that it is relatively easy to con- 
trol. The author only has one person's idea to grasp and interrogate, and one person to guide through the interview's agenda [10]. The other advantage of indepth interviews is that the author has the chance to capture non-verbal cues, including body language, emotions, behaviors, and reactions to the interview questions [11].

\section{SELECTION OF PARTICIPANTS}

Participants were selected to represent different sectors within the population fabric, for example, government sectors such as the Madinah Municipality and the Madinah Development Authority, academic sectors such as university members of staff and teachers in the education sector, and the private sector such as architects and museums' owners.

They were selected according to the following criteria:

1. Senior people who lived in the traditional houses of Madinah in the pre-demolition period and had real experience with the traditional architectural heritage of Madinah.

2. Those who concerned about the cultural heritage and had efforts, such as establishing museums, writing books and encyclopedias, and publishing articles in specialized journals, to save the traditional architectural heritage of Madinah.

3. Decision-makers who worked as senior consultants in the local government sectors concerned with the urban design of Madinah, such as the Madinah Municipality and the Madinah Development Authority.

4. Those who expressed a cultural identity in their projects and were involved in designing the building projects in Madinah.

\section{SAMPLE SIZE}

The sample size was selected based on the literature review, which demonstrated that 15 respondents provide an adequate and appropriate sample size in qualitative research studies, as Bertaux recommended [12]. In this study, the author decided to stop interviews after 15 participants had been interviewed; at this time, the author started to recognize that the data were repeating itself and concluded that enough data had been collected.

\section{ETHICAL STANCE}

Ethical consent was discussed, and approval was granted by the ethical committee of the Faculty of Art, Design, and Humanities at De Montfort University before starting the interviews.

\section{ANALYSIS OF INTERVIEWS}

The interviews were conducted in Arabic and were recorded after obtaining permission from interviewees with note-taking. Then the interviews were transcribed in Arabic verbatim and then translated from Arabic to English. The transcripts were reviewed and reread from time to time, which helped the author to familiarise herself with the data. Thematic analysis, using NVIVO software, was used to analyze the interview data by identifying codes, sub-codes, and themes based on issues raised by the study participants.

\section{DISCUSSION}

\section{BACKGROUND OF THE INTERVIEWEES}

The author asked each interviewee to provide a brief personal profile and outline of professional experience. Table 1 shows the general background of the study participants. As noted from Table 1, the majority of study participants were Saudis, PhD-holders from Saudi/Arabic universities, architects with more than 30 years' experience in their fields, and worked in the public sector. Table 2 summarises the participants' characteristics numerically and by percentages.

During the data analysis, seven broad themes were identified: (1) attitudes toward the vernacular architecture of Madinah; (2) attitudes toward the contemporary architecture of Madinah; (3) reasons behind dwindling traditional architectural identity in contemporary building designs; (4) attempts to revive traditional architectural identity in contemporary architecture; (5) the Stakeholders/Key players responsible for determining the pattern and style of design in the contemporary building system, (6) the importance of preserving the traditional architectural elements, especially Rowshan, within contemporary architecture in Madinah and (7) awareness of the public of Madinah of the Rowshan legacy.

\section{ATTITUDES TOWARD THE VERNACULAR ARCHITECTURE OF MADINAH}

In the beginning, the participants were asked to simply describe what they knew about the vernacular architecture of Madinah. The purpose of this question was to explore the attitude of the interviewees about the importance of the traditional architecture of Madinah and its unique elements. Participants in the study were very proud of the local architecture of their city, specifically the beauty of the traditional houses in Madinah, where described the façades of traditional buildings as a valuable source of a variety of ornamentations. It is illustrated in the following quotes:

"Traditional buildings of Madinah were considered as a valuable collection of some decorations, which essentially included Rawāshīn and doors." (Participant \#1)

"In terms of the decorative aspects of the city's old houses, the buildings were known for the beauty of the doors and windows. It could be noticed in the carved volcanic stones and the patterned bricks, along with the wooden doors adorned with Islamic artistry. The windows had the finest types of wood called Rowshan, which is a type of projecting oriel window enclosed with carved wood latticework." (Participant \#2)

Two participants pointed out that the traditional houses of Madinah were constructed according to human needs and social conventions. They stated:

"Based on the cultural and religious background of the homeowners, the building of such houses drew on religious, economic, social, and environmental principles and were overall attached as a unit. One of these princi- 
Table 1. The general background of the study participants.

\begin{tabular}{|c|c|c|c|c|c|c|c|}
\hline $\begin{array}{l}\text { Num- } \\
\text { ber }\end{array}$ & Code & $\begin{array}{l}\text { Nation- } \\
\text { ality }\end{array}$ & $\begin{array}{l}\text { Occu- } \\
\text { pation }\end{array}$ & $\begin{array}{l}\text { Qualifica- } \\
\text { tion }\end{array}$ & $\begin{array}{l}\text { Work } \\
\text { sector }\end{array}$ & Experience & $\begin{array}{l}\text { Years of } \\
\text { work } \\
\text { experi- } \\
\text { ence }\end{array}$ \\
\hline 1 & AAK & Saudi & $\begin{array}{l}\text { Archi- } \\
\text { tect }\end{array}$ & $\mathrm{PhD} / \mathrm{UK}$ & Private & $\begin{array}{l}\text { 1. A founder and owner of the Dar Al Madinah Museum. } \\
\text { 2. An architectural consultant at the Madinah Develop- } \\
\text { ment Authority. } \\
\text { 3. An author of several books, encyclopedias, and articles } \\
\text { about the traditional architectural heritage of Madinah. }\end{array}$ & 30 years \\
\hline 2 & $\mathrm{HAH}$ & Saudi & Artisan & $\begin{array}{c}\text { MA/Saudi } \\
\text { Arabia }\end{array}$ & Public & $\begin{array}{l}\text { 1. A supervisor in the Art Department at General Direc- } \\
\text { torate of Education. } \\
\text { 2. An art teacher in several primary and secondary } \\
\text { schools in Madinah. }\end{array}$ & 20 years \\
\hline 3 & $\mathrm{ABA}$ & Saudi & $\begin{array}{l}\text { Archi- } \\
\text { tect }\end{array}$ & $\begin{array}{l}\text { Ph.D./ } \\
\text { USA }\end{array}$ & Public & $\begin{array}{l}\text { 1. An architectural consultant at the Madinah Municipali- } \\
\text { ty. } \\
\text { 2. The head of the Engineering Department at King Ab- } \\
\text { dulaziz Endowment Project. }\end{array}$ & 35 years \\
\hline 4 & MAA & Saudi & $\begin{array}{l}\text { Archi- } \\
\text { tect }\end{array}$ & $\mathrm{PhD} / \mathrm{USA}$ & Public & $\begin{array}{l}\text { 1. A professor of architecture, Department of Architec- } \\
\text { ture and Planning at Faculty of Architecture, King Saud } \\
\text { University, Saudi Arabia. } \\
\text { 2. An author of several books and articles about the } \\
\text { traditional architectural heritage of Madinah. }\end{array}$ & 35 years \\
\hline 5 & WSH & Syrian & $\begin{array}{l}\text { Archi- } \\
\text { tect }\end{array}$ & $\begin{array}{l}\text { B.Arch./ } \\
\text { Syria }\end{array}$ & Private & $\begin{array}{l}\text { 1. Worked as an architectural consultant at Qara Consult- } \\
\text { ing Office. } \\
\text { 2. Participate in the implementation of many residential } \\
\text { and commercial designs in Madinah. }\end{array}$ & 20 years \\
\hline 6 & $\mathrm{AHA}$ & $\begin{array}{l}\text { Jorda- } \\
\text { nian }\end{array}$ & $\begin{array}{l}\text { Archi- } \\
\text { tect }\end{array}$ & $\begin{array}{l}\text { Ph.D./ } \\
\text { Italy }\end{array}$ & Public & $\begin{array}{l}\text { 1. A professor of architecture, Department of Architec- } \\
\text { tural Engineering at Faculty of Engineering, Taibah Uni- } \\
\text { versity, Saudi Arabia. } \\
\text { 2. An architectural consultant at the Madinah Municipali- } \\
\text { ty. }\end{array}$ & 30 years \\
\hline 7 & MHA & Saudi & $\begin{array}{l}\text { Archi- } \\
\text { tect }\end{array}$ & $\mathrm{PhD} /$ USA & Public & $\begin{array}{l}\text { 1. An associate professor of architecture, Department of } \\
\text { Architectural Engineering at Faculty of Engineering, } \\
\text { Taibah University, Saudi Arabia. } \\
\text { 2. An architectural consultant at the Madinah Municipali- } \\
\text { ty. }\end{array}$ & 25 years \\
\hline 8 & SMZ & Saudi & $\begin{array}{l}\text { Archi- } \\
\text { tect }\end{array}$ & $\mathrm{PhD} / \mathrm{USA}$ & Public & $\begin{array}{l}\text { 1. An associate professor of architecture, Department of } \\
\text { Architectural Engineering at Faculty of Engineering, } \\
\text { Taibah University, Saudi Arabia. } \\
\text { 2. An architectural consultant at the Madinah Municipali- } \\
\text { ty. }\end{array}$ & 22 years \\
\hline 9 & WAA & Saudi & Artisan & Ph.D./UK & Public & $\begin{array}{l}\text { 1. An associate professor of Art, Department of Art and } \\
\text { Design at Faculty of Arts and Humanities, Taibah Univer- } \\
\text { sity, Saudi Arabia. } \\
\text { 2. An author of several books and articles about the } \\
\text { traditional architectural heritage of Madinah. }\end{array}$ & 32 years \\
\hline 10 & $\mathrm{AMH}$ & $\begin{array}{l}\text { Egyp- } \\
\text { tian }\end{array}$ & $\begin{array}{l}\text { Archi- } \\
\text { tect }\end{array}$ & $\begin{array}{l}\text { Ph.D./ } \\
\text { Egypt }\end{array}$ & Private & $\begin{array}{l}\text { 1. Worked as an architectural consultant at Alshebel } \\
\text { Consulting Office. } \\
\text { 2. Participate in the implementation of many residential } \\
\text { and commercial designs in Madinah. }\end{array}$ & 35 years \\
\hline 11 & MSA & Saudi & $\begin{array}{l}\text { Archi- } \\
\text { tect }\end{array}$ & $\begin{array}{l}\text { B.Arch./ } \\
\text { Saudi } \\
\text { Arabia }\end{array}$ & Public & $\begin{array}{l}\text { 1. An architectural consultant at the Saudi Commission } \\
\text { for Tourism and National Heritage in Madinah. }\end{array}$ & 10 years \\
\hline 12 & EMA & Saudi & $\begin{array}{l}\text { Archae- } \\
\text { ologist }\end{array}$ & $\begin{array}{l}\text { BSc./ } \\
\text { Saudi } \\
\text { Arabia }\end{array}$ & Public & $\begin{array}{l}\text { 1. An author and historian of the architectural heritage of } \\
\text { Madinah. }\end{array}$ & 27 years \\
\hline 13 & ASS & Saudi & $\begin{array}{l}\text { Archi- } \\
\text { tect }\end{array}$ & $\begin{array}{l}\text { B.Arch./ } \\
\text { Saudi } \\
\text { Arabia }\end{array}$ & Private & $\begin{array}{l}\text { 1. A consultant engineer and Board Member at Taiba } \\
\text { Holding Company. } \\
\text { 2. The president of the Saudi Society for Urban Sciences } \\
\text { in Madinah. }\end{array}$ & 35 years \\
\hline 14 & AAA & Saudi & $\begin{array}{l}\text { Archae- } \\
\text { ologist }\end{array}$ & $\begin{array}{l}\text { BSc./ } \\
\text { Saudi } \\
\text { Arabia }\end{array}$ & Public & $\begin{array}{l}\text { 1. An author and historian of the architectural heritage of } \\
\text { Madinah. }\end{array}$ & 25 years \\
\hline 15 & JMO & $\begin{array}{l}\text { Egyp- } \\
\text { tian }\end{array}$ & $\begin{array}{l}\text { Archi- } \\
\text { tect }\end{array}$ & $\begin{array}{l}\text { Ph.D./ } \\
\text { Egypt }\end{array}$ & Public & $\begin{array}{l}\text { 1. A consultant of Urban Design and Development at the } \\
\text { Madinah Development Authority. } \\
\text { 2. An associate professor of Architecture and Urban } \\
\text { Design at Ain Shams University in Cairo, Egypt. }\end{array}$ & 35 years \\
\hline
\end{tabular}


Table 2: Characteristics of participants in numbers $(n=)$ and percentages (\%).

\begin{tabular}{lcc}
\hline Variables & Numbers (n) & Percentage (\%) \\
\hline Nationality & 11 & $73.4 \%$ \\
Saudi & 4 & $26.6 \%$ \\
Non-Saudi & & \\
Educational level & 5 & $33.3 \%$ \\
Bachelor & 1 & $6.7 \%$ \\
Master & 9 & $60 \%$ \\
PhD & & \\
Country of qualification & 8 & $53.3 \%$ \\
Saudi/Arabic Universities & 7 & $46.7 \%$ \\
Western Universities & & $13.3 \%$ \\
Specialization & 2 & $73.4 \%$ \\
Art and Design & 11 & $13.3 \%$ \\
Architecture & 2 & $26.6 \%$ \\
Archaeology & & $40.1 \%$ \\
Years of experience & $33.3 \%$ \\
10-20 & 4 & $73.4 \%$ \\
$21-30$ & 5 & $26.6 \%$ \\
>30 & 6 & \\
Work sector & 11 & 4 \\
Public & 4 & \\
Private & & \\
\hline
\end{tabular}

ples is to respect the rights and privacy of the neighbors and to reflect that in the construction of the houses." (Participant \#5).

In addition, two participants pointed out that there were factors that led to the formation of this unique urban character of Madinah, such as the geographical location of the city where different cultures converge, as well as the spread of skilled craftsmen and the travel of local people abroad and the influence of other cultures on them.

"Madinah was a hub where all cultures would meet. All the craftsmen had the knack and skill to go about these crafts, and so did the local merchants. It was a well -developed urban society for this type of art. This was also helped by local merchants' travels abroad and the effect of other cultures on them. This has led to the formation of architectural identity and urban character as a salient fabric." (Participant \#3)

Most of the participants in this study had positive attitudes towards Rowshan, as it was a symbol of traditional Islamic identity within the general architectural representation of Madinah for centuries. Rowshan (pl. Rawāshīn) is the projected latticework window, commonly found in façades of traditional dwellings in Madinah.

"Madinah has always been known for its unique urban and architectural character. This has been manifested in Rawäshin that occupied a large section of the traditional houses façades. Using Rawāshin became a major feature of Madinah, and people have for long been familiar with this type of art in the decoration of their houses façades." (Participant \#5)

Several participants pointed out that Rawāshin offered the traditional houses the aesthetic appeal that people strived to achieve.

"The traditional houses of Madinah were characterized by the use of Rawäshin, which offered the traditional houses the aesthetic appeal or status that many of the rich families strived to achieve." (Participant \#10)
"One could tell of the landlord is rich or poor by the styles and patterns of the traditional Rawäshin and the quality of the carvings." (Participant \#2)

Rowshan also played an essential role in performing vital functions inside dwellings, such as controlling ventilation and daylight while ensuring privacy.

"Rowshan did not provide only a decorative and aesthetic element, but also it was designed to perform several environmental functions, such as adjustment of lighting, humidity and airflow control, reducing the heat and playing an essential role in securing privacy. Additionally, it should not be ignored that Rowshan imbued life and vibrancy to the façades of traditional buildings in Madinah, which were previously extremely bare and gave a solid and harsh impression due to the heavy walls." (Participant \#4)

"The urban fabric of the city consisted of houses with façades and Rawāshin, which can sometimes be protruding or non-protruding, at the same levels the walls. This helped the airflow in a way that was proportionate to the hot local climate." (Participant \#3)

\section{ATTITUDES TOWARD THE CONTEMPORARY ARCHITECTURE OF MADINAH}

When the participants were asked to express their attitudes toward the contemporary architecture of Madinah, it was noted that the majority of the study participants had negative attitudes toward the contemporary architecture and were severely concerned about the gradual erosion of the traditional architectural identity in the building industry in Madinah. The following quotes explain this:

"In contemporary trends, we have not been able to catch up with the Western character, nor have we been able to preserve the traditional character. The presence of skyscrapers in the city is not in keeping with the urban fabric and the religious status of the city. It is also at odds with the environment." (Participant \#3) 
"The current situation in the building industry in Madinah can be best described as a "mishmash." This is a Western term used when there is no specific underlining philosophy. Therefore, if an architect has no guiding principles, they may resort to a mixture of terms and cultures from here and there, and this why there is no distinctive character." (Participant \#5)

Participants claimed that the materials used in contemporary dwellings' façades are not compatible and contradict with the environment of Madinah.

"In my opinion, I can say that contemporary architectural façades designs are not suitable for a city like Madinah and harm people's lives as well." (Participant \#6)

"In my opinion, curtain walls, cladding, and glass are the most materials used in decorating the façades of contemporary buildings in Madinah. These materials came from abroad, mostly from the West, which is not suitable for our environment. For instance, the use of vast expanses of glass in modern buildings is not wholly appropriate for the environment of Madinah, requiring continual interior climate control." (Participant \#1) (Figure 3).
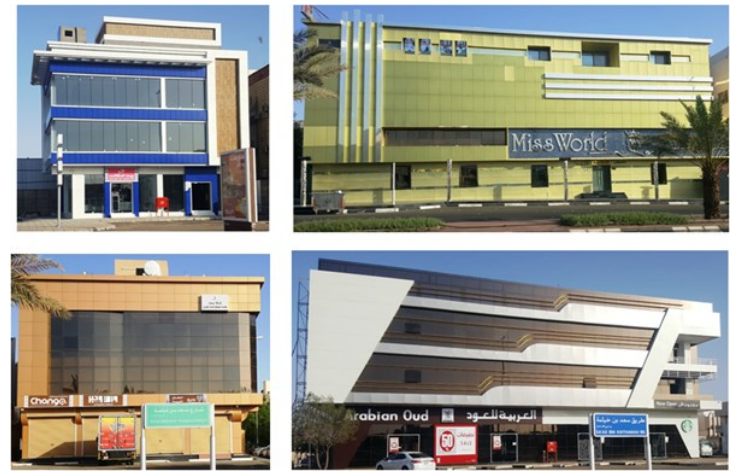

Figure 3: Examples of materials used in decorating the façades of contemporary buildings in Madinah.

REASON BEHIND DWINDLING TRADITIONAL ARCHITECTURAL IDENTITY IN CONTEMPORARY ARCHITECTURE IN MADINAH

When participants were asked to identify the reasons behind the increasing erosion of the traditional Islamic style of architectural design in Madinah, several reasons were identified, which include the followings:

1. The demolishing processes of the traditional architectural heritage in the Central District for giving room for the Prophet Mosque's expansion and mega developmental projects. "A great deal of this immense collections of the Madinah heritage has been removed for Prophet Mosque's expansion, and only as little as one percent has been retained." (Participant \#1)

2. Globalization and the openness to global markets and gaining access to building materials and new construction techniques for the country to use as an alternative to traditional materials. "The massive importations of concrete and rein forced concrete into the local market made people wonder about this swift and quality construction model. As a result of this method, houses have become like concrete boxes isolated from the surrounding environment." (Participant \#5)

3. Lack of craftsmen and professionals who promote new designs of traditional architectural elements to keep abreast of the latest developments. "Other contributing factors include the extinction of handicrafts and artisans, as well as youth reluctance to pursue a career path in handicrafts and the decision of a large number of craftsmen to leave their jobs as a result of lack of demand and the costly materials." (Participant \#1)

4. Recruitment of skilled foreign labor and technical expertise that allowed the construction sector to benefit from new methods and techniques that parted way with the identity of Madinah. "The Engineering Consultant Offices ignored the local identity of the city too. This is because of the foreign architects who work in these offices who have no idea about the architectural legacy of Madinah, and their professional engagement with their clients is based on service delivery in return for profit-making only." (Participant \#10)

5. Lack or inefficiency of academic efforts in terms of promoting awareness regarding the importance of heritage the preservation of local identity. "There appears to be lack and inefficiency in terms of academic efforts, in addition to the role of education in the preservation of identity. There also seems to be a lack of focus of vocational/arts education curricula in fostering student love of Islamic art and identity and in developing some kind of rapport between them and their past and heritage." (Participant \#1)

6. Lack of laws and regulations imposed by local governmental authorities to enforce building plans and style standards that would include the traditional Islamic style of building design. "It seems that the local authorities have failed to map out clear rules and guidelines for contemporary architectural designs which were based on the traditional Islamic style of building." (Participant \#1)

\section{ATTEMPTS TO REVIVE TRADDITIONAL ARCHITECTURAL IDEN- TITY IN CONTEMPORARY ARCHITECTURE IN MADINAH}

The participants were asked to evaluate the current attempts of reviving the local cultural identity within contemporary architecture in Madinah. In response to this question, participants underestimated the significance of these attempts as they have not been evaluated carefully and studied meticulously by the professionals. These attempts, as the participants believed, did more harm than good to the local authentic architectural identity. The following quotes from the participants clarify this:

"Some tried hard to reintroduce Rawāshin, but with the use of the aluminum material because the wood material peels off with extreme heat. This, however, caused the Rawäshin to lose the distinctive element of the wood and the beautiful patterns with which they are associated." (Participant \#5) (Figure 4).

However, two participants pointed out that there are still a few projects in Madinah that have succeeded 
in integrating contemporary design with local identity. They stated:

"We have Rasem Badran who tried to add urban and arabesque character to the Heritage neighborhood at King Fahd Park, which he began but did not finish nor did he invest the idea of the project. It is a restructuring of the terms and elements in Madinah." (Participant \#5)

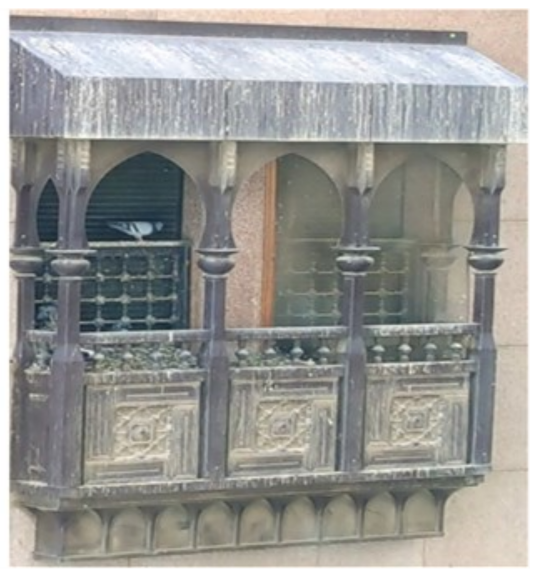

Figure 4: Rowshan in a state of neglect and disuse on the façade of one of the hotels in the Central District, as a result of using the wrong material in constructing Rowshan.

"There are some attempts to restore identity and the architectural environment. For example, the Rawäshīn was reproduced, but it has lost the most important characteristic, which is its function. This is because it has not been studied, and the focus has only been on the external form without delving deeper." (Participant \#7) (Figure 5).

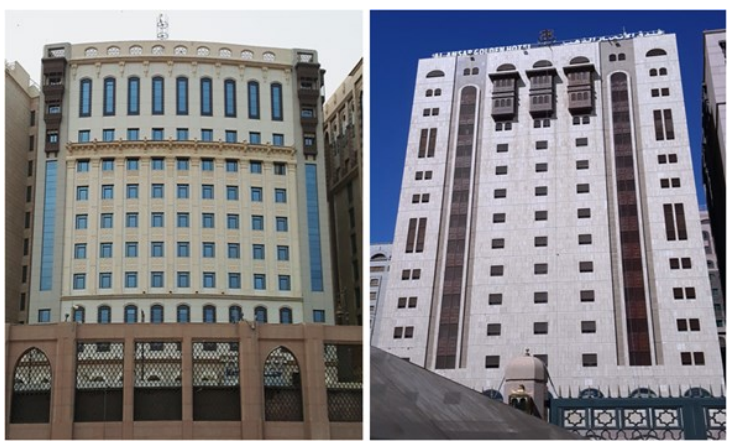

Figure 5: Other examples of the false Rowshan in the Central District show the discrepancy between the size of Rowshan and the façade of the building. It is also noted that Rowshan's place on the top floors indicates that Rowshan was added to the building without any study or minimal knowledge of its basic functions.

THE STAKEHOLDERS/KEY PLAYERS RESPONSIBLE FOR DETERMINING THE PATTERN AND STYLE OF DESIGN IN THE CONTEMPORARY BUILDING SYSTEM IN MADINAH

From the interviewees' point of view, it could be concluded that governmental authorities such as the Madinah Municipality and the Madinah Development Authority, Engineering Consultant Offices, and house owners are the main key players in determining the design of the contemporary architecture in Madinah. And they have a role and a responsibility for essential decisions on building design, which has resulted in the gradual disappearance of the local architectural identity in contemporary architecture. The following quotes illustrate this:

"There are no clear rules and regulations imposed by the Madinah Municipality and the Madinah Development Authority to ensure that the pattern and nature are homogeneous of building throughout the city. This led to what I can describe as the "visual pollution" in the building industry in Madinah." (Participant \#4)

"The house owners: They depend on their knowledge and have little or no experience. They just want to convey what they see during their travels and then try to describe it to the Engineering Consultant Office. Most house owners want to have a house as soon as possible and with the lowest price without taking into account the quality aspect." (Participant \#7)

"The Engineering Consultant Offices offer limited opinions. The office task is to meet the requirements of the owner. The architectural design is based on the personal, intellectual, cultural, economic, and social taste of the owner. There is thus diversity but also a lack of urban aesthetic character in the façades of the buildings. What we see today is personal convictions based on a specific line of thought, which are simply intellectual chaos." (Participant \#5)

THE IMPORTANCE OF PRESERVING THE TRADITIONAL ARCHITECTURAL ELEMENTS WITHIN CONTEMPORARY ARCHITECTURE IN MADINAH

The study participants were asked: Do you consider it might be relevant to rethink using traditional architectural elements, specifically Rowshan, within contemporary architecture in Madinah? It could be seen that most of those interviewed believe that Rowshan's legacy is of great value in Madinah society. Thus, the need to preserve it within contemporary architecture is crucial. However, they also pointed out that it is important to preserve Rowshan in the context of redeveloping and creating new patterns of designs that would integrate form and function within the buildings' design in Madinah. Participants' quotes illustrate this:

"A human being without identity has lost his personality and roots. Therefore, I strongly recommend that Rowshan should be incorporated in the design of contemporary buildings in Madinah, because it is part of its identity and suits the environment and the cultural orientation of people of Madinah." (Participant \#7)

"We must acknowledge that Rowshan needs to be addressed in the design of contemporary buildings in Madinah, provided that the form of Rowshan is integrated with its function." (Participant \#3)

One participant focused on Rowshan's construction materials and emphasized that Rowshan should be constructed of eco-friendly and heat-insulating materials.

"I agree with the idea of reviving Rowshan in our con- 
temporary houses in Madinah. But I emphasize the need to manufacture these Rawäshin of eco-friendly and heatinsulating materials." (Participant \#14)

However, two participants believe that there is no point in restoring Rowshan in contemporary houses in Madinah as it is too costly, outdated and reflects the old cultural values. The following quotes describe their point of view:

"I think that it is necessary to take into account the rapid development and changes over time; if a person decided to reuse Rawāshin as a design solution for their house, this would not look normal compared the rest of the buildings in the city because the architecture of the city has detached itself from the local identity. Moreover, the industry of Rawāshin is becoming too costly nowadays." (Participant \#8)

"Although we are proud of our history and societal values, I believe that there is no point in restoring Rowshan in the design of contemporary architecture in Madinah. Simply, because it is part of the past and is suitable for past generations, each generation should be allowed to express themselves in a new and fashionable way different from the past." (Participant \#9)

\section{AWARENESS OF THE PUBLIC OF MADINAH OF THE ROW-} SHAN'S LEGACY

The participants were asked: Do you believe that the people of Madinah have an awareness of the Rowshan's legacy?

From the interviewees' point of view, it could be concluded that the people of Madinah, especially the elderly, cherish their heritage and are keen to revive Rowshan in their homes. The following citations illustrate this:

"The people of Madinah have a passion and feel nostalgic for Rowshan heritage. They also yearn to revive Rowshan in their homes, but they do not have the intellectual knowledge to realize the importance of this heritage." (Participant \#6)

"The feeling of nostalgia is only experienced when people look at old photos and visit museums, but I expect that adults and older people may feel more nostalgic and a stronger attachment because they were part of it. This is why they call for Rowshan to be restored in modern design plans as a step of the reinstatement of local identity." (Participant \#1)

\section{DISCUSSION}

In the present study, the interviewees were consistent in acknowledging that the massive demolishing processes of irreplaceable monuments in the Central District around the Prophet's Mosque was one of the most important factors behind the significant decline in Rowshan's use in the current architectural scene of Madinah. Equally, the current attempts of reviving the local cultural identity within contemporary architecture in Madinah have not been evaluated carefully and studied meticulously by the professionals, thereby, did more harm than good to the local authentic architectural identity. Similar findings have been reported by Al -Mahdy and Al-Harthi. They found that the develop- ment project of the Central District undertook a mass development for the historical area without considering the traditional and historical values of the place [4] [5].

In addition, the interviewees were consistent in acknowledging the recent changes in the entire pattern of architectural identity within contemporary architecture in Madinah and were very concerned about the phenomenon of diminishing traditional architectural identity in Madinah. With regards to the nature of stakeholders responsible for the transformation of contemporary architectural styles and patterns in Madinah, it could be concluded from the survey interviews that governmental authorities, such as the Madinah Municipality and the Madinah Development Authority, Engineering Consultant Offices and house owners are the main key players, according to the interviewees' point of view. Both the Madinah Municipality and the Madinah Development Authority contributed negatively. They failed to encourage the promotion and preservation of the traditional Islamic style of building within contemporary architectural designs in Madinah. The majority of the Engineering Consultant Offices today appeared to have little real knowledge about the traditional Islamic style of design and not interested in identity and urban character. Based on the interviewees' opinions, due to lack of awareness and understanding of the value of traditional Islamic style of design, it is clear that house owners were looking for the cheapest and the quickest alternative designs regardless of their appeal to taste or harmony with the environment. They just want to convey what they see during their travels and then try to describe it to the Engineering Consultant Office. Such cultural reorientation is brought about by people's preferences for modernity due to Western influences. Al-Kandari and Mahjoub from Kuwait, who also found similar results, mentioned that there is a clear erosion of the traditional architectural identity in contemporary Kuwaiti architecture. This may be due to the negative contribution of stakeholders or key players, such as the Kuwaiti Municipality and the Engineering Consultant Offices, who have now lost control of their traditional role in terms of determining the style, building structure, and type in Kuwait. Due to their attitudinal changes and desires towards a Western-style of building, the house owners are not aware of the possible implications of this attitude in terms of the erosion of the local cultural identity [9] [13].

Other factors that contributed for the gradual erosion of the architectural identity in Madinah are the globalization and openness to global markets and gaining access to new building materials that were incompatible with the city's environment and the cultural orientation of the Madani people, lack of craftsmen and professionals, recruitment of foreign labor and technical expertise that allowed the construction sector to benefit from new methods and techniques that gave no cognizance to the nature of the city's environment nor its authentic identity, the inefficiency of academic efforts in terms of promoting awareness regard- 
ing the importance of heritage and the preservation of local identity and lack of laws and regulations imposed by local governmental authorities to enforce building regulations that could encourage the traditional Islamic style of building design. In his study, Al-Hussayen found that the gradual erosion of the architectural identity in Madinah could be attributed to several factors, such as the globalization and openness to global markets and new building materials, lack of skilled labor and recruitment of foreign (non-Arab) investors and businesses. They gave no cognizance to the nature of the city's environment nor its authentic identity [14].

Although there were several attempts accomplished by the local authorities in the form of reintroducing Rowshan in contemporary architecture in Madinah in order to promote the restoration of identity and heritage, with the use of inappropriate materials, these attempts had not been successful and became a burden on the consumers. These attempts, as the participants noticed, had not been evaluated carefully and studied meticulously by the professionals, which did more harm than good to Rowshan because it was added without a comprehensive study of all the important functional and aesthetic aspects that are the basis of the concept of Rowshan. Rowshan is created in wood as it is a natural insulator that prevents the burning rays of the sun reaching the building, and it is a material that resists natural conditions [15]. It should be taken into account when constructing Rowshan from new alternative materials other than wood that these materials have properties somewhat similar to wood, in relation to absorption and evaporation issues, as well as the flexibility of the wood that allows the craftsman to design a wide variety of Rowshan styles and patterns [16].

The present study empirically contributes to knowledge by applying theoretical social science research through conducting interviews with experts in Madinah to explore their opinions toward the erosion of the traditional architectural identity within contemporary architecture in Madinah, as well as the ensuing decline in the use of Rowshan element that defines this particular style of architecture and ascertaining whether they are interested in reviving Rowshan element in their architectural projects. To the best of the researcher's knowledge, little previous scholarly work has been undertaken regarding rethinking the elements of architectural heritage, but not from the region of Madinah.

\section{CONCLUSION}

In conclusion, overriding opinions concluded that Rowshan's legacy is of great value in Madinah society, and the need to preserve it within contemporary architecture is essential. The respondents' opinions also agreed that ways should be found to develop Rowshan's designs, which would ensure that the form of Rowshan is integrated with its function.

\section{ACKNOWLEDGMENT}

We extend our sincere thanks to Taibah University, the Ministry of Education in Saudi Arabia, and the Saudi Arabian Cultural Bureau in the United Kingdom for their constant encouragement and support.

\section{REFERENCES}

[1] AFP, “Haj Pilgrim Spending Jumps by 70 Percent; Saudi Arabia Hopes to Draw Six Million Pilgrims Annually by 2030," Gulf News, 2017. [Online]. Available: https://gulfnews.com/ world/gulf/saudi/haj-pilgrim-spending-jumps-by70-per-cent-1.2084376. [Accessed: 10-Dec2006].

[2] C. International, "Kingdom of Saudi Arabia Holy Cities on the Road to Re-Development," 2014. [Online]. Available: https://www.colliers.com/-/ me-

dia/7447BF6144684A1F8420B5C0348F25CA.ash x?la=en-GB. [Accessed: 30-Apr-2017].

[3] J. Taylor, "Medina: Saudis Take a Bulldozer to Islam's History," Independent, 2012. [Online]. Available: https://www.independent.co.uk/ news/world/middle-east/medina-saudis-take-abulldozer-to-islams-history-8228795.html. [Accessed: 28-Feb-2016].

[4] O. Al-Mahdy, "Madinah: Reviving Place Identity through Public Space," University of Waterloo, 2013.

[5] W. Al-Harthi, "Investigation into the Impact of Using Virtual Heritage to Depict the Historical City of Al Madinah," University of Kent, 2015.

[6] A. A. Al Haija and J. A. Al Haija, "Medina Traditional Roshan- the Effected," in XIV International Conference on World Heritage and Degradation: Smart Design, Planning and Technologies Role, 2016.

[7] S. Omer, "Masjid al-Haram Expansion: the Case of Shamiyyah," IslamiCity, 2019. [Online]. Available: islamicity.org/18918/masjid-al-haramexpansion-the-case-of-shamiyyah/. [Accessed: 12-Jul-2019].

[8] M. Al-Naim, "Identity in Transitional Context: Open-Ended Local Architecture in Saudi Arabia," Archnet-IJAR, International Journal of Architectural Research, vol.2, pp. 125-146, 2008.

[9] F. Al-Kandari, "Islamic ceramic ornamentation and process: Proposals for a new aesthetic vocabulary in contemporary architectural embellishment within Kuwait," University of Central Lancashire, 2011.

[10] M. Hamed, "The development of a framework for design of web presence and associated online marketing strategy for museums in Saudi Arabia," De Montfort University, 2016.

[11] M. Hennink, I. Hutter, and A. Bailey, Qualitative research methods. London: Sage Publications. 2010.

[12] D. Bertaux, "From the Life-History Approach to the Transformation of Sociological Practice", In Biography and society: The life history approach in the social sciences, London: Sage 
Press, 1981.

[13] Y. Mahgoub, "Architecture and the expression of cultural identity in Kuwait," The Journal of Architecture, vol.12, pp. 165-182, 2007.

[14] M. Al-Hussayen, "Al-Rowshan Onsur Wazefi wa Jamali fe Wajehat Masaken Al-Madinah AlMunawarah Altaqlediyah: Alwsol ela Taqyees Wehdatoh Waajzaaoh," Journal of King Saud
University, vol.14, pp.19-51, 2002.

[15] F. Al-Murahhem, "The mechanism of the rawāshinn: the case study of Makkah," WIT Transactions on Ecology and the Environment, vol.128, pp. 561-573, 2010.

[16] H. Alothman, "An Evaluative and Critical Study of Mashrabiya in Contemporary Architecture," Near East University, 2017. 